\begin{tabular}{|l|l|}
\hline $\begin{array}{l}\text { 2. To: (Receiving Organization) } \\
\text { DISTROBUTION }\end{array}$ & $\begin{array}{l}\text { 3. From: (Originating Organization) } \\
\text { DC LARSEN/SST TWRS LMH }\end{array}$ \\
\hline 5. Proj./Prog./Dept./Div.: & $\begin{array}{l}\text { 6. Design Authority/ Design Agent/cog. } \\
\text { Engr:: }\end{array}$ \\
\hline
\end{tabular}

This ATR documents completion of ATP HNF-1516. "Thermocouple Module Halt Failure Acceptance Test Procedure for Tank 241SY-101".
11. Receiver Remarks:
11A. Design Baseline Document?
[] Yes
$[x]$ No
$N / A$

8. Originator Remarks:

4. Related EDT No.: 606762

7. Purchase order No.:

$\mathrm{N} / \mathrm{A}$

9. Equip./Component No.:

N/A

10. System/8ldg./Facility: 241-SY-101/DACS-1.

12. Major Assm. Dwg. No.:

N/A

13. Permit/Permit Application No.: $\mathrm{N} / \mathrm{A}$

14. Required Response Date: $\mathrm{N} / \mathrm{A}$

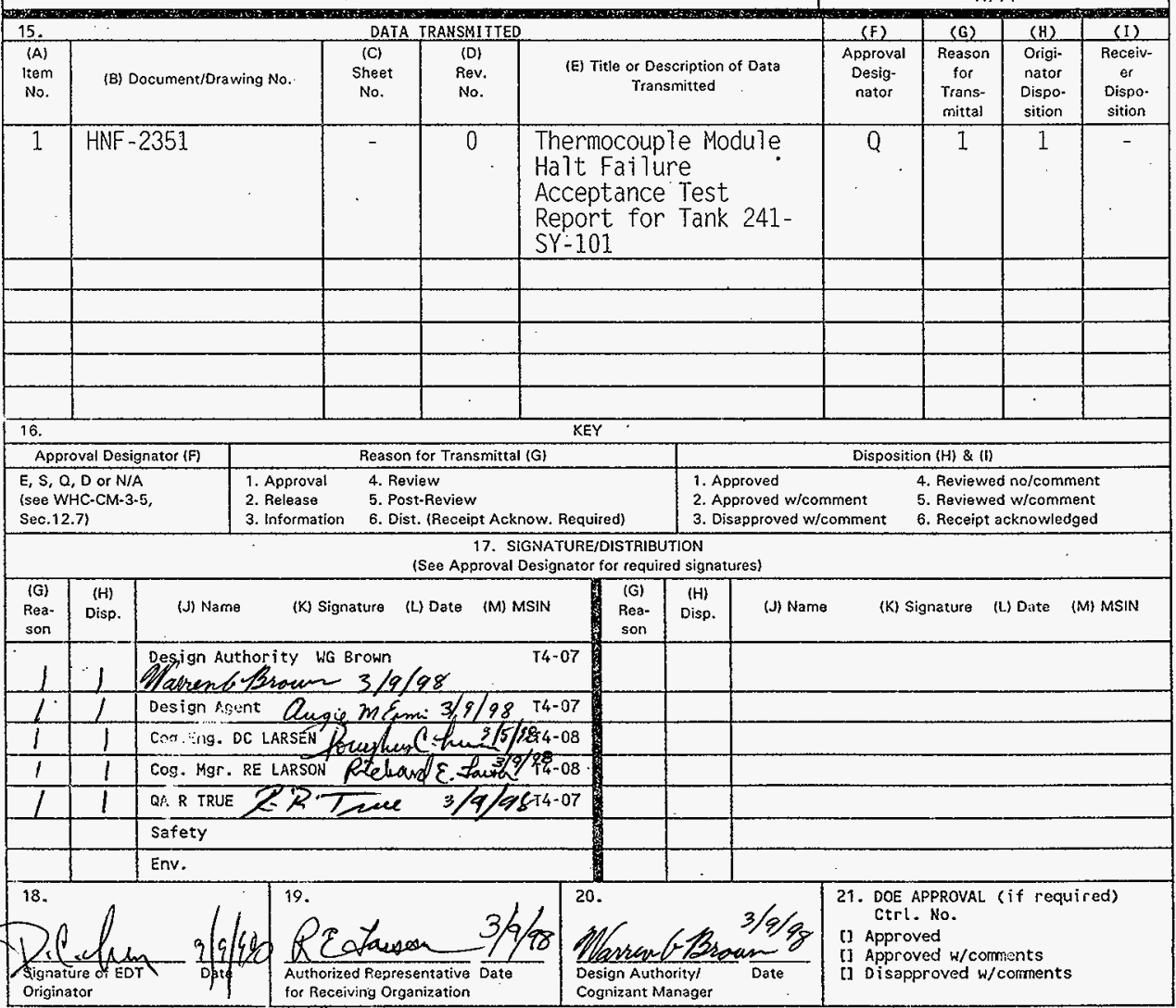




\title{
THERMOCOUPLE MODULE HALT ACCEPTANCE TEST REPORT FOR TANK 241-SY-101 DACS-1
}

\author{
DOUGLAS C. LARSEN \\ LMH. Richiand, WA 99352 \\ U.S. Department of Energy Contract DE-AC06-96RL13200 \\ EDT/ECN: 621176 \\ Org Code: 79460 \\ BRR Code: \\ UC: \\ Charge Code: $\quad$ $16 B 1$ y 2 simen \\ Total Pages: 3536
}

Key Words: 241-SY-101, DACS, SOFTWARE, MIXER PUMP. THERMOCOUPLE, MIT

Abstract: The following documents the acceptance test report for the 241-SY-101 modicon module software testing performed as a corrective action to communications problem.

TRADEMARK DISCLAIMER. Reference herein to any specific commercial product, process, or service by trade name, trademark, manufacturer, or otherwise, does not necessarily constitute or imply its endorsement, recommendation, or favoring by the United States Government or any agency thereof or its contractors or subcontractors.

Printed in the United States of America. To obtain copies of this document, contact: Document Control Services, P.0. Box 950, Mailstop H6-08, Richland WA 99352, Phone (509) 372-2420; Fax (509) 376-4989.
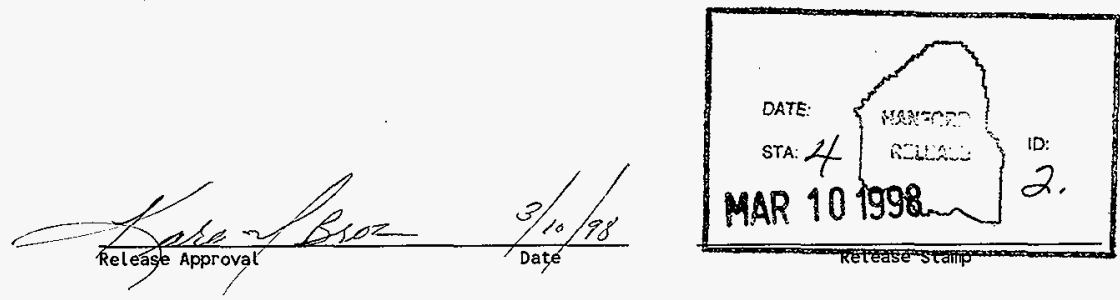

Approved for Public Release 


\section{THERMOCOUPLE MODULE HALT FAILURE ACCEPTANCE TEST REPORT FOR TANK 241-SY-101 DACS-1 \\ HNF-2351 REVISION 0}

MARCH 5, 1998 


\section{TABLE OF CONTENTS}

Summary of HNF-2351, Rev. 0, "THERMOCOUPLE MODULE HALT FAILURE ACCEPTANCE TEST REPORT FOR TANK 241-SY-101 DACS-1".

Completed acceptance test procedure 
SUMMARY OF HNF-2351, ReV. 0, "THERMOCOUPLE MODULE HALT FAILURE ACCEPTANCE TEST REPORT FOR TANK 241-SY-101 DACS-1".

Testing was started on February 24, 1998 and completed on February 25, 1998.

The completed procedure consists of 4 acceptance test sections, 6.1 through 6.4.

Three test exceptions were identified during the procedure. The first test exception was determined to be unrelated to the ATP and unfortunate that the instrument failed during the ATP. The next two test exceptions were disposition as acceptable because the alarming functions worked correctly in identifying a problem when software communications were interrupted. The test was completed satisfactorily over 2 days.

The remainder of the acceptance test report is the completed test procedure.

\%ocUMGNIO.




\section{DISTRIBUTION SHEET}

\begin{tabular}{|c|c|c|c|c|c|}
\hline \multirow{2}{*}{$\begin{array}{l}\text { To } \\
\text { Distribution }\end{array}$} & \multirow{2}{*}{\multicolumn{3}{|c|}{$\begin{array}{l}\text { From } \\
\text { SESC / Laboratory Services }\end{array}$}} & \multicolumn{2}{|l|}{ Page 1 of 1} \\
\hline & & & & \multicolumn{2}{|c|}{ October $29 ; 1997$} \\
\hline \multicolumn{4}{|l|}{ Project Title/Work Order } & \multicolumn{2}{|c|}{ EDT No. 606762} \\
\hline \multicolumn{4}{|c|}{$\begin{array}{l}\text { Thermocouple Module Halt Failure Acceptance Test Procedure for Tank } \\
\text { 241-SY-101 DACS-1 / NF22Y }\end{array}$} & \multicolumn{2}{|l|}{ ECN No. } \\
\hline Name & MSIN & $\begin{array}{l}\text { Text } \\
\text { With All } \\
\text { Attach. }\end{array}$ & Text Oniy & $\begin{array}{c}\text { Attach } I \\
\text { Appendix } \\
\text { Only }\end{array}$ & $\begin{array}{l}\mathrm{EDT} / \mathrm{ECN} \\
\text { Only }\end{array}$ \\
\hline W. G. Brown & T4-07 & $\mathrm{X}$ & & & \\
\hline D. W. Crass & H6-11 & & & & $\mathrm{X}$ \\
\hline J. A. Ellingsworth & R2-87 & $\mathrm{x}$ & & & \\
\hline A. M. Ermi & L6-37 & $\mathrm{X}$ & & $\cdot$ & \\
\hline G. J. Gauck & T4-07 & $\mathrm{X}$ & & 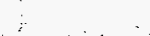 & \\
\hline L. S. Krogsrud & T4-07 & $\mathrm{X}$ & & & \\
\hline D. C. Larsen & T4-08. & $\mathrm{X}$ & & . & \\
\hline D. D. Tate & L6-37 & & & & $\mathrm{X}$ \\
\hline R.W. Truitt & L6-37 & $\mathrm{X}$ & & & \\
\hline R. R. True & T4-07 & $\mathrm{X}$ & & & \\
\hline R. P. Tucker & T4-08 & & & & $\mathrm{x}$ \\
\hline S. O. Smith / A. C. Zuehlke & L6.37 & $\mathrm{x}$ & & & \\
\hline DACS Project File & L6-37 & $\mathrm{x}$ & & . & \\
\hline Central Files & B1-07 & $\mathrm{X}$ & & & \\
\hline
\end{tabular}


2. To: (Receiving Organization)

Distribution

5. Proj.Prog./Dept./Div.:

241SY101 Mitigation Project

8. Originator Remarks:

This ATP tests the 241SY101 DACS software following changes designed to monitor and prevent thermocouple module halt failures.

(Reference: DACS change control board System Change Request \#427)

\section{Receiver Remarks: ... 11A. Design Baseline Document? [ ] Yes $[\mathbb{X}]$ No}

Reference USQ:TF-97-0929
3. From: (Originating Organization)

AM Emi / SESC Laboratory Services

6. Design Authority / Cog. Engr.:

GJ Gauck

- Pago 1 of 1

1. ЕDT 606762

$\therefore \ldots$...

\section{N/A}

13. PermidPermit Application No.:

N/A

14. Required Response Date:

$11 / 7 / 97$

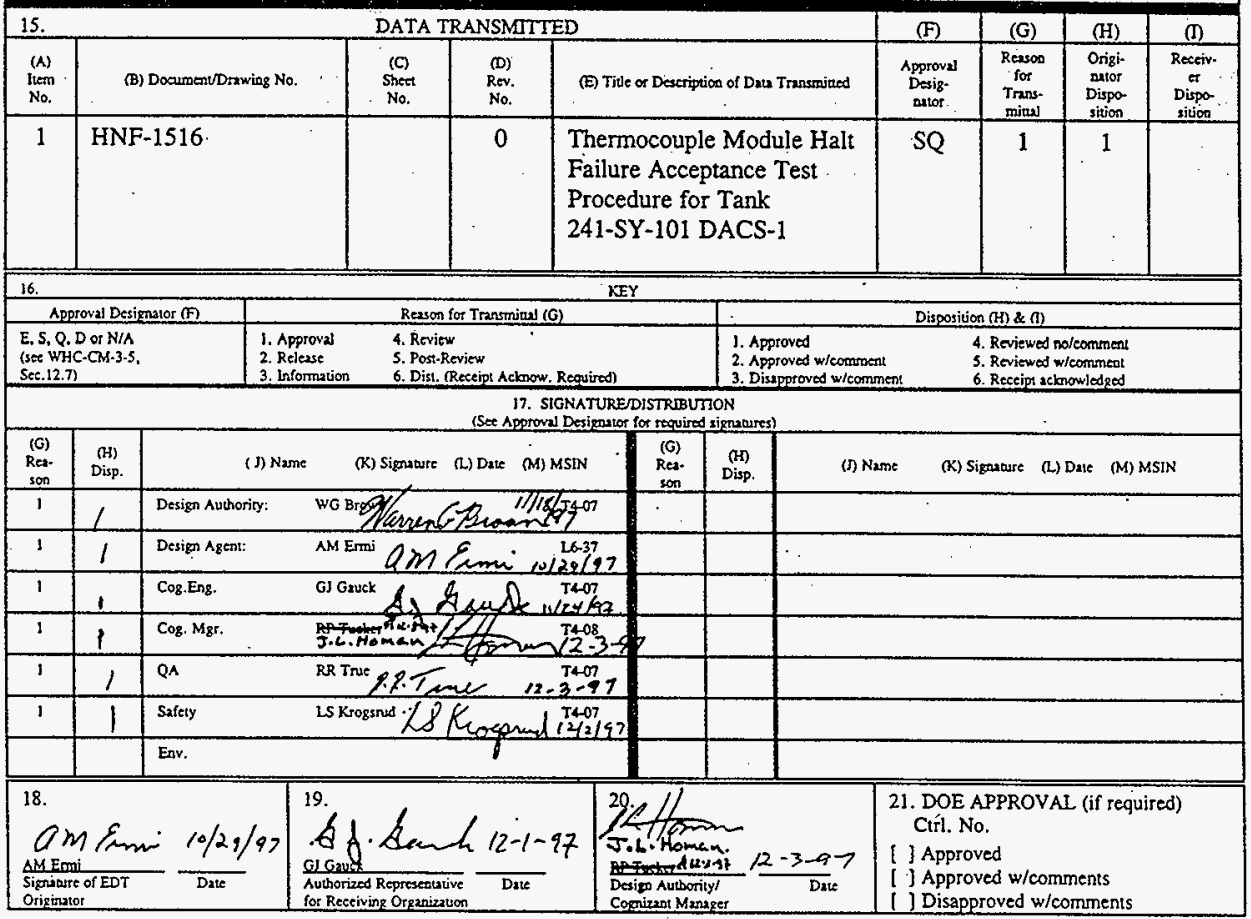

BD-7400-172-2 (05/96) GEF097

HNF-2351, Rev. 0 Page 5 of 35 
HNF-1516, Rev. 0

\title{
THERMOCOUPLE MODULE HALT FAILURE ACCEPTANCE TEST PROCEDURE FOR TANK 241-SY-101 DACS-1
}

\author{
A. M. Ermi \\ SGN Eurisys Services Corporation, P.O. Box 840, Richland, WA 99352 \\ U.S. Department of Energy Contract DE-AC06-96RL13200
}
EDT: 606762
Org Code: $\$ 4000$
UC: 2030
B\&R Code: EW3120072
Charge Code: NF22Y
Total Pages: 30

Key Words: DACS, DATA ACQUISITION AND CONTROL SYSTEM, 241SY101, ACCEPTANCE TEST PLAN, THERMOCOUPLE

Abstract: The readiness of the Tank 241-SY-101 Data Acquisition and Control System (DACS-1) to provide monitoring and alarms for a halt failure of any thermocouple moduie will be tested during the performance of this procedure. Updated DACS-1 "I/O MODULE HEALTH STATUS", "MININ1", and "MININ2" screens, which now provide indication of thermocouple module failure, will also be tested as part of this procedure.

TRADEMARK DISCLAIMER. Reference herein to any specific commercial product, process, or service by trade name, trademark, manufacturer, or otherwise. does not necessarily constitute or imply its endorsement, fecommendation, or favoring by the United States Government or any agency thereof or its contractors or subcontractors.

Printed in the United States of America. To obtain copies of this document, contact: Document Control Services, P.O. Box 950, Mailstop H6-08, Richland WA 99352, Phone (509) 372-2420; Fax (509) 376-4989.

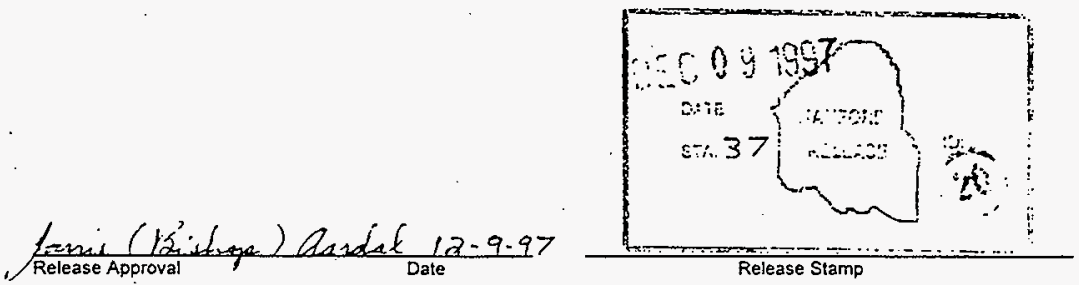

Approved for Public Release 
HNF-1516

Revision 0

Thermocouple Module Halt Failure

Acceptance Test Procedure

For Tank 241-SY-101 DACS-1

October 1997

Prepared by:

A. C. Zuehlke, PLCs Plus

Prepared for:

G. J. Gauck,

Lockheed Martin Hanford Corporation

HNF-2351, Rev. 0 Page 7 of 35 


\section{TABLE OF CONTENTS}

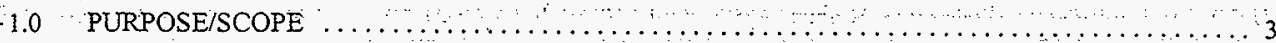

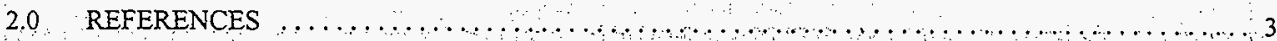

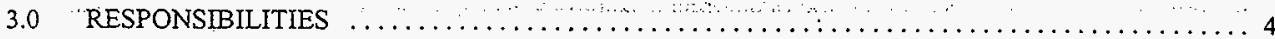

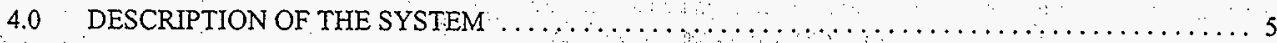

5.0 TEST CONDITIONS AND EQUIPMENT REQUIRED $\ldots \ldots \ldots \ldots \ldots \ldots \ldots \ldots \ldots \ldots \ldots \ldots$

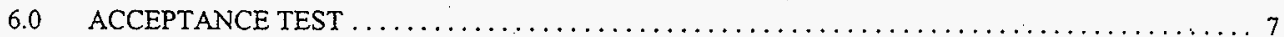

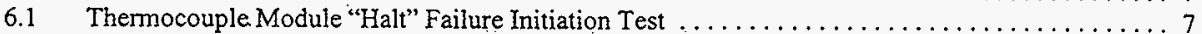

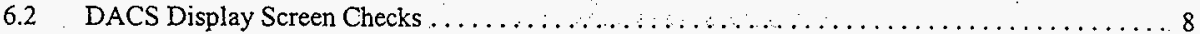

6.3 Instrumentation End-To-End Checks (17B MIT) $\ldots \ldots \ldots \ldots \ldots \ldots \ldots \ldots \ldots \ldots \ldots \ldots \ldots$

$6.4 \ldots$ Selected MIT17C and TBST Thermocouple End-To-End Checks $\ldots \ldots \ldots \ldots \ldots \ldots \ldots$

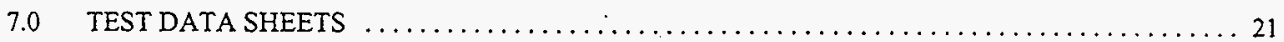

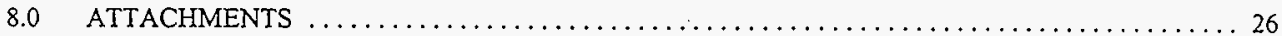

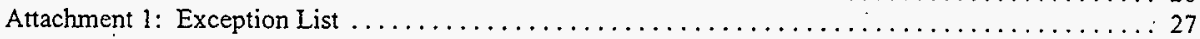

Attachment 2: Measurement and Test Equipment Record Sheet $\ldots \ldots \ldots \ldots \ldots \ldots \ldots \ldots \ldots \ldots$

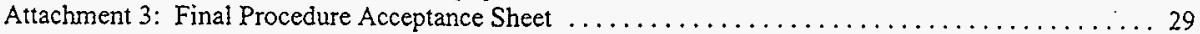

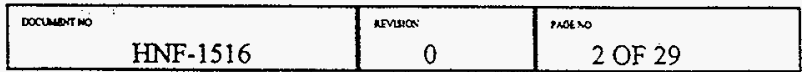




\subsection{PURPOSE/SCOPE}

The readiness of the Data Acquisition and Control System (DACS) to provide monitoring and alarms lor a halt failure of any thermocouple module will be tested during the performanec of this procedure.

Updated DACS "T/OMODULE HEALTH STATUS", "MNTN1", and "MNIN2" scrcens, which now. provide indication of themocouple module failure, will also be tested as a part of this procedure.

\subsection{REFERENCES}

2.1 HSR-C.M, Rev. 2, Hanford Site Raciological Control Manual

2.2 LAUR-92-3196, "Safety Assessment for Proposed Pump Operation to Mitigatc Episodic Gas Releases in Tank 241-SY-101"

2.3 Hanford Site Policies and Proccourcs, Occupational Safety and Health

2.4 HNF.PRO-423, Radiolegical Work Parmit

2.5 HNF-PRO-440, Engineering Document Change Control Requireouenls

2.6 HNF.PRO-446, Iesting Practices Requiremcats

2.7 WHC-IP-0263-TF, Wesinghouse Hanford Company Building Emergency Plan, Appendix $G, " \mathrm{~s}$. Fann Complex"

2.8 H.NF-IP-0842, Waste Tank Projccl Administration, Volume 2, Section 4.9.1, "Lockout Tagout"

2.9 WHC.SD-WM-HSP-002, Tank Farm Health and Safely Plan

\begin{tabular}{|c|c|c|}
\hline mexnery & eenem & mext: \\
\hline
\end{tabular}




\subsection{RESPONSIBILITIES}

The following personnel will be reguired for the performance of this procedure:

- Cognizant Engineer: The individual assigned direct responsibility for the preparation, performance, and adequacy of the test. Also responsible for final approval of resolutions for all exceptions on Attachment 1, "Exception list".

- . Test Directar: The engineer assigned shift responsibility for performancc of the test.

- Test Engincer: The engineer assigned to assist and relieve the Test Director duning the pcrformancc of the test.

- Field Engineer: A Test Director, Test Enginecr, or Technician assigned to direct/verify testing activitics outside of the DACS trailer.

Only personnel designatcd by the Shif Operations Manager are allowed to direct testing por this procedure, and perform operating and control functions using the DACS compuler systems.

One cngincer acting as either a Test Director or as a Test Engineer is rcquired to be present in the DACS trailer. One engincer or tcchnician acting as a Field Engineer and onc or morc Instrumen. Technicians and/or Electricians are required to inject test signals from outsirie of the DACS trailer.

If, during testing, any indicated parameter, control function, or screen display is nol correct or appears to be malfunctioning, then the engineer conducling this test shall make a determination is to the feasibility of continuing lesting. In most cases, since actual mixer pump motor operation will nol occur during this test. there will be no safety impact to continuing the tcst and completing corrective actions latcr. A record of all noted deficiencies will be kept on Altachment I, "Exception List".

At the completion of all testing, approval of all data collecled and DACSS system pcrfornunce shall be documented on Amachment 3. "Final Procedure Acceptance Shecl".

All changes to this procedurc shall be implemented by ECN, and shall receive the approval signatures appropriate to the approval designation of the change.

\begin{tabular}{|r|r|r|}
\hline HNF 1516 & 0 & LOF 29 \\
\hline
\end{tabular}




\subsection{DESCRIPTION OF THE SYSTEM}

The DACS, which is houscd in a trailer located just outside of the north fence at the SY tank farn, receives input signals from a varicty of sensors located in and around the SY-101 tank. These scnsors provide information such as:

- Tank vapor space and ventilation system $\mathrm{H}_{2}$ concentration

- Tank waste iemperature

- Tank pressurc

- Waste density

- Operating pump parameters such as speed, 1low, rotational position, discharge pressurc, and intemal temperature

- Waste level

The output of these sensors is conditioned and transmittcd to the DACS computers where these signals arc displayed, recorded, and monitored for out-of-specification conditions.

This procedure will test signals transmitted to the DACS from various MIT and Tank Bottum and Side Themocouples (TBST), and verify proper indication and alarms should the $1 / O$ modules associated with thesc themocouples experience a "halt"failure.

\subsection{TEST CONDITIONS AND EQUIPMENT REQUIRED}

5.1 The provisions of the following manuals apply 10 all work performed under this procecture:

- HSR-CM, Rev. 2. Hanford Site Radiological Contrel Manual

- Hanford Site Policies and Proccdures, Occupational Safety and Hcalth

- HNF-PRO-423, Radiological Work Pcrmit

- WHC-SD-WM-HSP-002, Tank Earn Health and Satety Plan

5.2 Lock and Tag Contro!

Locks and Tags shall be posted as requircd by HNF-IP-0842, Waste Tank Project Administration. Volume 2, Section 4.9.1, "Lockout/Tagout"

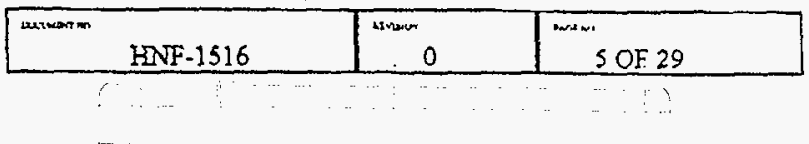

HNF-2351, Rev. 0 Page 11 of 35 
5.3 Jumpers and Lifted Leads

In this procedure, there are some occasions when leads will be lifted and landed at various terminals. Some of these leads will be energized. All required hand and eye protection shall be worn, and insulated tools shall be used, when working on energized circuits (<50 Vac). Testing must be conducted with energized instrument leads to correctly simulate a sensor input signal from the sensor to the DACS computers.

\subsection{Unexpected Alarms}

If unexpected, non-DACS, tank farm equipment alarms or abnormal indications are received during testing at the DACS trailer or in the SY tank farm, then SY-101 testing evolutions shall be immediately suspended and actions, as prescribed in approved Tank Farms Alarm Response and Emergency Procedures, shall be taken by Tank Farms Operations personnel to place the equipment/farm in a safe, stable condition. When the reason for the unexpected condition is understood and resolved, then SY-101 testing activities may be resumed after permission to do 50 is received from the responsible West Area Shift Manager (WASM) and the Cognizant Engineer.

5.5 Prior to initiation of testing, the following items shall be verified:

5.5.1 The changed version of the software has been loaded on the DACS trailer computers and the software has been released for testing.

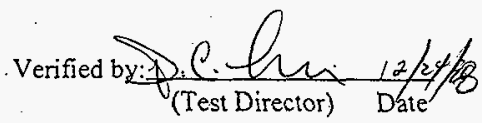

5.6 Prior to initiation of testing, the following equipment shall be available for use:

5.6.1 Insulated hand tools normally required for accessing equipment cabinets and terminal boards

5.6.2 Any anti-contamination clothing and/or other personnel safety equipment required for access to the SY tank farm, and to perform work on energized equipment $(<50 \mathrm{Vac})$

5.6.3 Radios ( 2 minimum) or other means of communications, for communicating between the DACS trailer and the SY tank farm

5.7 Omega CL-24, Thermocouple Calibrator, capable of generating a 0.397 to $3.819 \mathrm{mV} \mathrm{DC}\left(50^{\circ} \mathrm{F}\right.$ to $200^{\circ} \mathrm{F}$ ) signal, required for providing input signals for thermocouple sensor channels to be tested

5.8 MIT Type K Thermocouple Test Box

5.9 Attachment 2, "Measurement and̉ Test Equipment Record Sheet", is included in Section 8.0 for recording data associated with $M \& T E$ used during the performance of this procedure.

\begin{tabular}{|c|c|c|c|}
\hline Dexumation & HNF-1516 & 0 & 6 OF 29 \\
\hline
\end{tabular}

HNF-2351, Rev. 0 Page 12 of 35 


\subsection{ACCEPTANCE TEST}

\subsection{Thermocouple Module "Halt" Eailure Initiation Test}

6.1.1 If any discrepancy is noted during testing, then record a description of the condition in Attachment 1 .

6.1.1.1 For each discrepancy recorded, enter an identifying number in the "EXCEPTION NUMBER" Column of Attachment 1.

6.1.1.2 Reproduce Attachment 1 as needed, and attach the additional pages to this procedure, to record all discrepancies noted during testing.

NOTE: The thermocouple module "halt" failure condition was caused by two successive, complete lossof-power evolutions to both the Primary and Standby PLCs in the DACS trailer. The software changes being tested by this ATP prevent the condition from happening again, regardless of the. number of loss-of-power evolutions which could occur in the future. Testing per this procedure will cause two successive loss-of-power evolutions and verify that the thermocouple module "halt" failure does not occur.

6.1 .2

6.1 .3

6.1 .4

6.1 .5

6.1 .6

6.1 .7

At Station \#5, display the "ALARM/EVENT SUMMARY" screen.

At Station \#6, display the "VO HEALTH STATUS" screen.

At Station \#7, display the "MNNIN1" screen.

At Station \#1, access the Modsoft program and verify that the displayed status for the following tags is " 0 ":

$\begin{array}{llll}\text { - TC1CFGERR: Address: } 438 & \text { - } & \text { TC2CFGERR: Address: } 447 \\ \text { TC3CFGERR: Address: } 456 & \text { - } & \text { TC4CFGERR: Address: } 467 \\ \text { TC5CFGERR: Address: } 476 & \text { TC } & \text { TC6CFGERR: Address: } 485 \\ \text { TC7CFGERR: Address: } 236 & \text { - } & \text { TC8CFGERR: Address: } 565 \\ \text { TC9CFGERR: Address: } 574 & & \end{array}$

Verify that no I/O module health status alarms are displayed on the "ALARM/EVENTT SUMMARY" screen.

At the instrumentation rack in the back of the DACS trailer, turn-off the power to the Primary PLC and, within one second, turn-off power to the Standby PIC.

\begin{tabular}{|c|c|c|}
\hline HNFF-1516 & 0 & 7 OF 29 \\
\hline
\end{tabular}


$6.18 \ldots . . .$. After 30 seconds, turn-on power to the Primary PLC and; within one second, turm-on power to the Standby PLC.

6.1.9 After 30 seconds, turn-off the power to the Primary PLC and, within one second, tum-off power to the Standby PLC.

6:1.10 After 30 seconds, turn-on power to the Primary PLC and, within one second, turn-on power to the Standby PLC.

6.1.11 Observe the DACS screens at Stations 5, 6, and 7 for a minimum of 1 minute and verify that no $J / O$ module health status alarms are received.

6.1.12 : At Station $\# 1$, verify that the displayed status for the following tags is " 0 ":

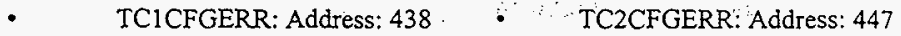

- TC3CFGERR: Address: 456 - TC4CFGERR: Address: 467

- TC5CFGERR: Address: 476 - . TC6CFGERR: Address: 485

- : TC7CFGERR: Address: $236 \quad$ a . TC8CFGERR: Address: 565

- TC9CFGERR: Address: 574

Testing as directed by this procedure section has been completed, and discrepancies, if any, have been listed on Attachment 1, Exception List.

Test Engineer: D. C. Tursuate: $2 / 24198$

\subsection{DACS Display Screen Checks}

6.2.1 If any discrepancy is noted during testing, then record a description of the condition in Attachment 1.

6.2.1.1 For each discrepancy recorded, enter an identifying number in the "EXCEPTION NUMMBER" Column of Attachment 1.

6.2.1.2 Reproduce Attachment 1 as needed, and attach the additional pages to this procedure, to record all discrepancies noted during testing.

6.2.2 At Station $\# 7$, verify on the "MININ1" and "MININ2" screens that all 22 of the "TIR17BXX" tags (associated with the 17B MIT) are displayed in WHITE letters.

6.2.3 At Station $\# 1$, disable tag "TC1CFGERR" and change the tag status to "l".

6.2.4 At Station \#5, verify that the "DIG 17CTCERR MIT17C I/O MODULE HALT" ERROR" alarm is displayed.

\begin{tabular}{|c|c|c|}
\hline Dorvexpi $\times 0$ & 0 & 8 OF 29 \\
\hline
\end{tabular}


6.2 .5

6.2 .6

6.2 .7

6.28

6.2 .9

6.2 .10

6.2 .11

At: Station \#6, verify that a.GREEN "OK" and a YELLOW "E" are displayed in the status block for Drop 4, Rack 2, Slot 4 .

At Station \#1, enable tag "TC1CFGERR" and verify that the status retums to " 0 ". At. Station \#5, verify that the "DIG 17CTCERR MIT.17C I/O MODULE HALT" ERROR" alarm is clear.

At Station \#6, verify that the YELLOW "E"is no longer visible in the block for Drop ? 4 , Rack 2, Slot 4.

At Station \#1, disable tag "TC2CFGERR" and change the tag status to." 1 ". V

At Station \#5, verify that the "DIG 17CTCERR MIT17C I/O MODULE HALT ERROR" alarm is displayed.

At Station \#6, verify that a GREEN "OK"and a YELLOW "E" are displayed in the status block for Drop 4, Rack 2, Slot 5.

At Station \#1, enable tag "TC2CFGERR" and verify that the status retums to " 0 ". $\checkmark$.

At Station \#5, verify that the "DIG 17CTCERR MIT17C NO MODULE HALT $/$ ERROR" alarm is clear.

At Station $\# 6$, verify that the YELLOW "E"is no longer visible in the block for Drop 4, Rack 2, Slot 5 .

At Station \#1, disable tag "TC3CFGERR" and change the tag status to "1".

At Station $\# 5$, verify that the "DIG 17CTCERR MIT17C I/O MODULE HAII" ERROR" alarm is displayed.

At Station \#6, verify that a GREEN "OK" and a YELLOW "E" are displayed in the status block for Drop 4, Rack 2, Slot 6.

At Station \#1, enable tag "TC3CFGERR" and verify that the status returns to " 0 ".

At Station \#5, verify that the "DIG 17CTCERR MIT17C VO MODULE HALT ERROR" alarm is clear.

At Station \#6, verify that the YELLOW "E"is no longer visible in the block for Drop 4, Rack 2, Slot 6.

\begin{tabular}{|c|c|c|}
\hline HNF-1516 & 0 & 9 OF 29 \\
\hline
\end{tabular}


6.2.21 At Station \#1, disable tag "TC4CFGERR" and change the tag status to "1".

6.2.22 At Station $\# 5$, verify that the "DIG TBSTCERR TBS VO MODULE HAIT ERROR" alarm is displayed.

At Station $\# 6$, verify that a GREEN "OK"and a YELLOW "E" are displayed in the $\mathscr{J}$ status block for Drop 13, Rack 1, Slot 4.

At Station \#1, enable tag "TC4CFGERR" and verify that the status returns to " 0 ".

At Station \#5, verify that the "DIG TBSTCERR TBS JO MODULE HALT * ERROR" alarm is clear.

At Station \#6, verify that the YELLOW "E"is no longer visible in the block for Drop 13, Rack 1, Slot 4.

At Station \#1, disable tag "TC5CFGERR" and change the tag status to "1"..

At Station $\$ 5$, verify that the "DIG TBSTCERR TBS VO MODULE HALT $\checkmark$. ERROR" alarm is displayed.

At Station \#6, verify that a GREEN "OK" and a YELLOW "E" are displayed in the status block for Drop 13, Rack 1, Slot 5.

At Station $\# 1$, enable tag "TC5CFGERR" and verify that the status returns to " 0 ".

At Station $\# 5$, verify that the "DIG TBSTCERR TBS I/O MODULE HALT $\checkmark$ ERROR" alarm is clear.

At Station \#6, verify that the YELLOW "E"is no longer visible in the block for Drop 13, Rack 1, Slot 5.

At Station \#1, disable tag "TC6CFGERR" and change the tag status to " 1 ". $\delta$ At Station $\# 5$, verify that the "DIG TBSTCERR TBS IOO MODULE HALT $\sqrt{ }$ ERROR" alarm is displayed.

At Station \#6, verify that a GREEN "OK"and a YELLOW "E" are displayed in the status block for Drop 13, Rack 1, Slot 6.

At Station \#1, enable tag "TC6CFGERR" and verify that the status returns to " 0 ".

\begin{tabular}{|c|c|c|}
\hline Docivertitos & 0 & 10 OF 29 \\
\hline
\end{tabular}


6.2 .37

6.2 .38

$6.2 .40^{\circ}$

At Station $\# 5$, verify that the "DIG TBSTCERR TBS LO MODULE HALT" ERROR" alarm is clear.

At Station \#6, verify that the YELLOW " $E$ "is no longer visible in the block for Drop 13, Rack 1, Slot 6.:

At Station $\# 1$, disable tag "TC7CFGERR" and change the tag status to ". 1 ".

At Station \#5, verify that the "DIG 17BTCERR MIT17B VO MODULE HAIT ERROR" alarm is displayed.

At Station \#6, verify that a GREEN "OK" and a YELLOW "E" are displayed in the status block for Drop 4, Rack 1, Slot 7.

NOTE: In order to check the display screens for all of the MIT17B thermocouple tags, the "MININ2" screen must be accessed at Station $\# 7$ also.

At Station $\#$, verify that the information for the following MIT 178 tags is displayed $\checkmark$ in RED letters:

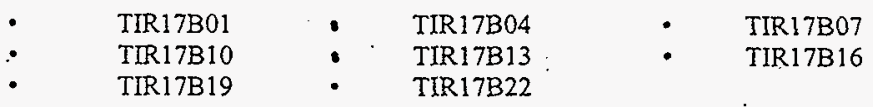

6.2.43 Verify that the information for the other MIT17B tags is displayed in WHITE letters.

6.2.44 Ai Station $\# 1$, enable tag "TC7CFGERR" and verify that the status retums to " 0 ".

6.2.45 At Station $\# 5$, verify that the "DIG 17BTCERR MIT17B I/O MODULE HALT $V$ ERROR" alarm is clear.

6.2.46 At Station \#6, verify that the YELLOW "E"is no longer visible in the block for Drop $V$ 4, Rack 1, Slot 7.

6.2.47 At Station \#1, disable tag "TC8CFGERR" and change the tag status to "1".

6.2.48 At Station $\# 5$, verify that the "DIG 17BTCERR MIT17B I/O MODULE HALT ERROR" alamm is displayed.

6.2.49 At Station \#6, verify that a GREEN "OK"and a YELLOW" $E$ " are displayed in the status block for Drop 4, Rack 2, Slot 3.

\begin{tabular}{|r|r|r|}
\hline HINF-1516 & $\begin{array}{r}\text { nemean } \\
0\end{array}$ & 11 OF 29 \\
\hline
\end{tabular}


At Station $\# 7$, verify that the information for the following MiTi7B tags is displayed in RED letters:

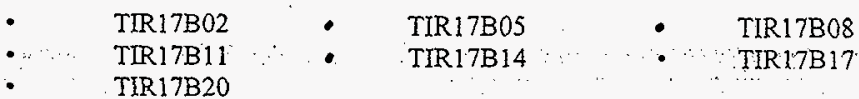

$6.2 .51: \quad$ Verify that the information for the other MIT17B tags is displayed in WHITE letters.

6.2 .52 : At Station \#1, enable tag "TC8CFGERR" and verify that the status returns to " 0 ".

$6.2 .53 \ldots$ At Station \#5, verify that the "DIG 17BTCERR MIT17B I/O MODULE HALT $d$ ERROR" alarm is clear.

6.2.54 At Station \#6, verify that the YELLOW "E" is no longer visible in the block for Drop 4, Rack 2, Slot 3.

At Station \#1, disable tag "TC9CFGERR" and change the tag status to " 1 ". J

At Station \#5, verify that the "DIG 17BTCERR MIT17B I/O MODULE HALT" ERROR" alarm is displayed.

At Station $\# 6$, verify that a GREEN "OK" and a YELLOW "E" are displayed in the status block for Drop 4, Rack 2, Slot 7.

At Station $\#$, verify that the information for the following MITl7B tags is displayed in RED letters:

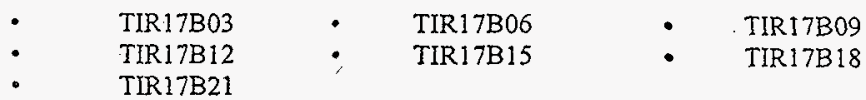

Verify that the information for the other MIT17B tags is displayed in WHITE letters. ERROR" alarm is clear.

At Station \#6, verify that the YELLOW "E" is no longer visible in the block for Drop 4 , Rack 2, Slot 7.

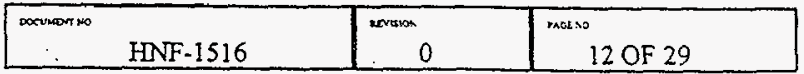



of the "TIR17BXX" tags (associated with the 17B MIT) are displayed in WHITE letters.

Testing as directed by this procedure section has been completed, and discrepancies, if any, have been listed on Attachment 1, Exception List:

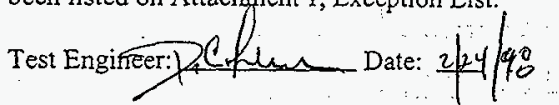

\subsection{Instrumentation End-To-End Checks (17B MUT)}

NOTE: - Performance of the steps in this procedure section requires that no other conflicting activities are taking place in the Control Area of the DACS trailer in conjunction with the testing to be performed, and that the computers and monitors at Stations $\$ 5, \# 6$, and $\# 7$ are available to support this test section.

6.3.1 If any discrepancy is noted during testing, then record a description of the condition in Attachment 1.

\subsubsection{For each discrepancy recorded, enter an identifying number in the "EXCEPTION NUMBER" Column of Attachment 1.}
6.3.1.2 Reproduce Attachment I as needed, and attach the additional pages to this procedure, to record all discrepancies noted during testing.

6.3.2 At Station \#5, display the "MIT17B" screen.

6.3.3 At Station \#6, display the "TEMPALM" screen.

6.3.4 At Station $\ddot{m}$ 7, display the "SUMMARY" screen.

NOTE: Steps for testing sensors in this section are written generically. Steps shall be repeated as necessary until required testing is complete.

Sensors shall be tested one at a time, until all have been tested.

Test signals shall be applied to the cable connector going to the $1 / O$ Module or DACS trailer, NOT back to the sensor.

6.3.5 Establish communications between field personnel in the SY tank fam and the Test Engineer in the DACS trailer.

\begin{tabular}{|c|c|c|}
\hline HNF -1516 & ansom 0 & 13 OF 29 \\
\hline
\end{tabular}


If testing in this section requires more than one shift to complete; then perform Steps 6.3.45 through 6.3.49 at the end of each shift.

\section{NOTE:}

The Test Engineer in the DACS trailer shall direct the performance of the activities in this section.

If necessary to complete testing, disable the ABORT coils associated with any 101 'SY'instruments that are sending erratic signals, are out-of-service, or are inoperable, at Station \#1.

NOTE: . Sensors may be tested in any order, at the discretion of the Test Director.

6.3.8 Record the current value displayed for all 17B MIT sensors on Station \#7, in the "B:" block in the "DACS READING" Column, on the appropriate data sheet.

6.3.9 Direct field personnel to disconnect the 17B MIT 55-pin connector at the MTT, ensure that the MIT Type $\mathrm{K}$ Thermocouple Test Box (test box) selector switch is in the OFF position, and connect the test box to the cable going to the GMS shack.

6.3.10 Direct field personnel to connect the thermocouple calibrator to the test box input jack.

6.3.11 Refer to the "DACS Tag" Column of the data sheets to locate the tag \# of the sensors to be tested.

6.3.12 Locate the DACS tag \# of the sensor to be tested at Stations $\# 5$, \#6, and $\# 7$.

6.3.13 Refer to the "SELECTOR SWITCH POSITION \#" Column of the data sheets, to direct field personnel in determining the correct switch position for the sensor to be tested.

6.3.14 Direct field personnel to position the selector switch for the sensor to be tested.

6.3.15 Direct field personnel to set the output of the thermocouple calibrator to the value listed in the "F:" block in the "LOW END READNG" Column, on the respective data sheet.

6.3.16 Observe the current value displayed at Station \#7 for the sensor being tested, and record the reading in the "D:" block of the "LOW END READING" Column.

\begin{tabular}{|c|c|c|}
\hline HNF-1516 & 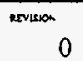 & MeE No 14 OF 29 \\
\hline
\end{tabular}


6.3.17 Direct field personnel to slowly increase the output of the thermocouple calibrator to the value listed in the "F:" block in the "MID RANGE READNG" Column of the respective data sheet.

6.3.18 .... Observe the current value displayed at Station \#7 for the sensor being tested, and record the reading in the "D:" block in the "MID RANGE READING" Column of the respective data sheet.

6.3.19 .... Direct field personnel to slowly increase the output of the thermocouple calibrator to the value listed in the "F:" block in the "HIGH END READING" Column of the respective data sheet.

6.3.20 Observe the current value displayed at Station $\# 7$ for the sensor being tested, and record the reading in the "D:" block in the "HIGH END READING" Column of the respective data sheet.

NOTE: $\quad$ Expected alarm and abort setpoints are listed in parenthesis in the "AL:" and "AB:" blocks respectively, in the ALARMABORT VALUES (DACS) column of the respective data sheet.

6.3.21 Direct field personnel to slowly reduce the output of the themocouple calibrator to a value below the alarm setpoint (AL:), listed in the ALARM/ABORT VALUES

(DACS) column of the respective data sheet for the sensor being tested.

6.3.22 At Station \#5, ensure that any alarms associated with the sensor being tested are clear ("ALARM/EVENT SUMMARY" screen).

6.3.23 Direct field personnel to slowly increase the output of the thermocouple calibrator until the associated alarm is actuated.

6.3.24 If the setpoint at which the alarm actuated is uncertain, then repeat Steps 6.3.21 through 6.3.23 until the alarm setpoint has been satisfactorily determined, then goto Step 6.3.25.

6.3.25 At Station $\$ 5$ verify:

- The displayed value for the sensor being tested is approximately equal to the value listed for the sensor in parenthesis in the "AL:" block on the data sheet.

- $\quad$ The displayed value is enclosed by a flashing YELLOW box.

- A visual and audible alarm have been received for the sensor being tested.

\begin{tabular}{|c|c|c|}
\hline HNF -1516 & 0 & 15 OF 29 \\
\hline
\end{tabular}


6.3:26 Acknowledge the alarm to silence the audible horn.

6.3.27 At Station \#6 verify:

- The displayed value for the sensor being tested is approximately equal to the value listed for the sensor in parenthesis in the "AL:" block on the data sheet.

- The DACS tag \# for the sensor being tested is displayed in RED letters.

6.3.28 At Station $\# 7$ verify that the displayed value for the sensor being tested is approximately equal to the value listed for the sensor in parenthesis in the "AL:" block on the data sheet.

6.3.29 Record the value at which the alarm actuated in the "AL:" block on the respective data sheet.

6.3.30 At Station.\#1, ensure that the abort coil associated with the sensor being tested is enabled.

6.3.31 Ensure that the E Stop circuitry is reset.

6.3.32 Direct field personnel to slowly increase the output of the thermocouple calibrator until the associated abort is actuated.

6.3.33 If the setpoint at which the abort actuated is uncertain, then reduce the output of the thermocouple calibrator to a value below the abor setpoint.

6.3.34 Repeat Steps 6.3.31 through 6.3.33 until the abort setpoint has been satisfactorily determined, then goto Step 6.3.35.

6.3.35 At Station $\# 5$ verify:

- The displayed value for the sensor being tested is approximately equal to the value listed for the sensor in parenthesis in the "AB:" block on the data sheet.

- The displayed value is enclosed by a flashing YELLOW box.

- A visual and audible alarm have been received for the sensor being tested.

6.3.36 Acknowledge the alarm to silence the audible hom.

\begin{tabular}{|c|c|c|}
\hline Docunati vo & Novios & 16 OF 29 \\
\hline
\end{tabular}


At Station $\# 6$ verify:

- The displayed value for the sensor being tested is approximately equal to the value listed for the sensor in parenthesis in the "AB:" block on the data sheet.

The DACS tag \# for the sensor being tested is displayed in RED letters:

A RED box is displayed to the left of the DACS tag \# for the sensor being tested.

$6.3 .38 \ldots \ldots$ At Station $\# 7$ verify that the displayed value for the sensor being tested is approximately equal to the value listed for the sensor in parenthesis in the "AB:" block on the data sheet.

6.3.39 Verify that an E Stop trip has been actuated.

6.3.40 Record the value at which the abort actuated in the "AB:" block on the respective data sheet.

6.3.41 Direct field personnel to decrease the output of the thermocouple calibrator to a value below the sensor alarm setpoint.

6.3.42 At Station $\#$, verify that all alarms associated with the sensor that was tested are clear.

6.3.43 Initial the "INITIALS" column for the sensor that was tested, if the test was completed satisfactorily.

6.3.44 : Repeat Steps 6.3.11 through 6.3.43, as necessary, until all 17B MIT sensors listed on the data sheets have been tested, then goto Step 6.3.45.

$\stackrel{=}{=}$

6.3.45 Direct field personnel to ensure that the test box selector switch is in OFF and that the thermocouple calibrator has been disconnected from the test box.

Direct field personnel to disconnect the test box from the MIT 55-pin connector and to reinstall the 55-pin connector onto the $17 \mathrm{~B}$ MIT.

Record the current.value displayed on Station \#7, for each sensor that was tested, in the "A:" block in the "DACS READING" Column on the appropriate data sheet.

Compare the pre-test (B:) and post-test (A:) readings taken in Step 6.3.8 and 6.3.47.

\begin{tabular}{|c|c|c|}
\hline cocturatios & REvisot & 17 OF 29 \\
\hline
\end{tabular}


6.3.48.1 If the pre-test and post-test readings are NOT consistent, then record a description of the inconsistency in Attachment 1.

Ensure that the data sheets have been initialed for all sensors that have been tested.

Testing as directed by this procedure section has been completed, and discrepancies, if any, have been listed on Attachment 1, Exception List.

Test Engineer:

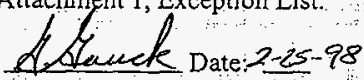

\subsection{Selected MITL7C and TBST Thermocouple End-To-End Checks}

6.4.1 If ary discrepancy is noted during testing, then record a description of the condition in Attachment 1.

\subsubsection{For each discrepancy recorded, enter an identifying number in the} "EXCEPTION NUMBER" Column of Attachment 1.

6.4.1.2 Reproduce Attachment 1 as needed, and attach the additional pages to this procedure, to record all discrepancies noted during testing.

6.4.2 Enter Level 3 passwords at Stations $\# 5$, \#6, and \#7.

NOTE: . Station $\# 8$ will NOT be used during testing per this section. Mixer pump motor and directional drive system motor power supply circuit breakers may remain danger tagged OFF for performance of this test section.

6.4.3 At Station $\# 5$, disply the "MIT17C" screen.

6.4.4 At Station \#6, display the "SUMMARY" screen.

6.4.5 At Station 4 7, display the "TBSTC" screen.

NOTES: Steps for testing instruments in this section are written generically. Steps shall be repeated as necessary until required testing is complete.

Instruments shall be tested one at a time, until all have been tested.

In general, test signals should be applied to a lifted lead, and should be verified to be applied to the cable going to the UO Module or DACS trailer, NOT back to the sensor.

\begin{tabular}{|c|c|c|c|}
\hline Decunour no & HNF-1516 & 0 & 18 OF 29 \\
\hline
\end{tabular}


6:4.6 Establish communications between field personnel in the SY tank farm and the Test Engineer in the DACS trailer.

NOTES: The Test Engineer at the DACS console shall direct the perfomance of the activities in this section.

Checks in this section may be performed in any order, by selecting the sensor to be tested and following the appropriate steps to establish the necessary prerequisite conditions.

$6.4 .7 \ldots \ldots$ Refer to the "DACS Tag" Column of the Test Data Sheets and locate the tag number of the sensor to be tested.

6.4 .8

Refer to the "Input Signal Connectn' Points" Column of the Data Sheets, to direct field personnel in locating the correct terminal(s) for the sensor to be tested.

\section{WARNING}

All required hand and eye protection shall be worm, and insulated tools shall be used; when working on or near energized electrical circuits $(<50 \mathrm{Vdc})$.

6.4.9 Direct field personnel to access the proper terminal board and locate the associated signal lead(s) for the sensor to be tested.

6.4.10 At Station \#5 or \#7, press the F2 key to display a "TAG" block in the lower portion of the screen.

6.4.11 Type in the DACS tag number for the sensor being tested.

6.4.12 Record the readout value displayed in the "AIN" block, in the "B:" block in the "DACS READING" Column, on the appropriate Data Sheet.

6.4.13 Direct field personnel to lift the lead(s) from the terminal board if necessary and connect the thermocouple calibrator.

6.4.14 Direct field personnel to set the output of the thermocouple calibrator to the value listed in the "F:" block in the "LOW END READING" Column, on the respective Data Sheet.

6.4.15 Observe the "AIN" value displayed at Station \#5 or \#7 for the sensor being tested, and record the reading in the "D:" block of the "LOW END READING" Column.

\begin{tabular}{|c|c|c|}
\hline HINF-1516 & 0 & 19 OF 29 \\
\hline
\end{tabular}


Direct field personnel to slowly increase the output of the thermocouple calibrator to the value listed in the "F:" block in the "MID RANGE READING" Column of the respective Data Sheet.

6.4.17 ..... Observe the "ADN" value displayed at Station $\$ 5$ or $\# 7$ for the sensor being tested, and record the reading in the "D:" block in the "MID RANGE READING" Column. of the respective Data Sheet.

6.4.18 Direct field personnel to slowly increase the output of the thermocouple calibrator to the value listed in the "F:" block in the "HIGH END READING" Column of the respective Data Sheet.

6.4.19 Observe the "AIN" value displayed at Station \#5 or \#7 for the sensor being tested, and record the reading in the "D:" block in the "HIGH END READNG" Column of the respective Data Sheet.

6.4.20 Direct field personnel to reconnect the sensor lead(s) to the proper terminal(s), if necessary.

6.4.21 Record the post-test sensor readout from the "Current Value" displayed on Station \#5 or \#7, for the instrument that was tested, in the "A:" block in the "DACS READING" Column on the appropriate Data Sheet.

6.4.22 Compare the pre-test (B:) and post-test (A:) readings taken in Steps 6.4.12 and 6.4.21.

\subsubsection{If the pre-test and post-test readings are not consistent, then record a description of the inconsistency in Attachment 1.}

6.4.23 Repeat Steps 6.4.7 through 6.4.22.1 to complete testing for sensors listed in the Test Data Sheets, then goto Step 6.4.24.

6.4.24 Direct field personnel to ensure that all leads are properly restored, and that all panels and covers have been restored to normal.

6.4.25 Initial all Data Sheets for sensors that have been successfully tested.

Testing as directed by this procedure section has been completed, and discrepancies, if any, have been listed on Attachment 1, Exception List.

Test Engineer:

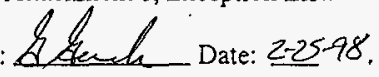

\begin{tabular}{|c|c|c|}
\hline HNF-1516 & 0 & 20 OF 29 \\
\hline
\end{tabular}




\section{THERMOCOUPLE MODULE HALT FAILURE ACCEPTANCE TEST PROCEDURE}

\subsection{TEST DATA SHEETS}

\begin{tabular}{|c|c|c|c|c|c|c|c|c|c|c|}
\hline $\begin{array}{l}\text { DACS } \\
\text { TAG }\end{array}$ & $\begin{array}{l}\text { FIELD TAG } \\
\text { NUMBER }\end{array}$ & DESCRIPTION & $\begin{array}{l}\text { SCALE/ } \\
\text { RANGE }\end{array}$ & $\begin{array}{l}\text { SELECTOR } \\
\text { SWITCH } \\
\text { POSITION \# }\end{array}$ & $\begin{array}{c}\text { DACS } \\
\text { READING }\end{array}$ & $\begin{array}{l}\text { LOW END } \\
\text { READING }\end{array}$ & $\begin{array}{c}\text { MID } \\
\text { RANGE } \\
\text { READING }\end{array}$ & $\begin{array}{l}\text { ALARM/ } \\
\text { ABORT } \\
\text { VALUES } \\
\text { (DACS) }\end{array}$ & $\begin{array}{c}\text { HIGH } \\
\text { END } \\
\text { READING }\end{array}$ & INITIALS \\
\hline \multirow[t]{2}{*}{ TIRI7BOI } & \multirow[t]{2}{*}{$T E-101-S Y-1713-01$} & \multirow[t]{2}{*}{$\begin{array}{l}\text { TANK TEMP RISER } \\
\text { 17B, L.EVEL 4" }\end{array}$} & \multirow[t]{2}{*}{$\underset{c}{12.5-325}$} & \multirow[t]{2}{*}{1} & $B: 111,80$ & $\mathrm{~F}: 71$ & $F: 105^{\circ}$ & $\begin{array}{l}\text { ALi: } 130.50 \\
(130)\end{array}$ & F: 139 & 4 \\
\hline & & & & & 111,40 & $D: 71.20$ & $D: 105.50$ & $\begin{array}{l}\text { AB: } 135,80 \\
(135) 13\end{array}$ & D: 139.60 & $\gamma$ \\
\hline \multirow[t]{2}{*}{ TIRI7B02 } & \multirow[t]{2}{*}{$T E-101-5 Y .17 B-02$} & \multirow[t]{2}{*}{$\begin{array}{l}\text { TANK TEMP RISER } \\
\text { 17B, LEVEL } 16^{\prime \prime}\end{array}$} & \multirow[t]{2}{*}{$\stackrel{12.5 \cdot 325}{\circ}$} & \multirow[t]{2}{*}{2} & B: 114,40 & $F: 71$ & F: 105 & $\begin{array}{l}\mathrm{AL}: 130.40 \\
(130)\end{array}$ & $\mathrm{F}: 139$ & \& \\
\hline & & & & & 113.90 & $0: 71,70$ & D: 105.30 & $(135) 135.90$ & D: 140,00 & 8 \\
\hline \multirow[t]{2}{*}{ TIRI7BO3 } & \multirow[t]{2}{*}{ TE-101-SY-17B-03 } & \multirow[t]{2}{*}{$\begin{array}{l}\text { TANK TEMP RISER } \\
\text { 17B, I.EVEL 28* }\end{array}$} & \multirow[t]{2}{*}{$\underbrace{12.5-325}_{n}$} & \multirow[t]{2}{*}{3} & B: 115.80 & $F: 71$ & F: 105 & AL: 130.50 & $F: 139$ & 8 \\
\hline & & & & & $A: 115,30$ & ${ }^{D}: 70,40$ & 104,40 & $\begin{array}{ll}13 & 135)^{\prime} \\
& 134,50\end{array}$ & $\mathrm{D}: 139,70$ & 9 \\
\hline \multirow[t]{2}{*}{ TIRI7B04 } & \multirow[t]{2}{*}{$78=101-5 Y-17 B-04$} & \multirow[t]{2}{*}{$\begin{array}{l}\text { TANK TEMP RISER } \\
\text { I7B, LEVEL } 52^{*}\end{array}$} & \multirow[t]{2}{*}{$\begin{array}{c}12.5-325 \\
-F\end{array}$} & \multirow[t]{2}{*}{4} & $\mathrm{~B}: \mathrm{H}$ & $F: 71$ & F: 105 & AL: 130.59 & $F: 139$ & 4 \\
\hline & & & & & A: 116,90 & $0: 71.9$ & 105.70 & $(135) 134,00$ & $\mathrm{D}: 138.20$ & 4 \\
\hline \multirow[t]{2}{*}{ TIRI7BOS } & \multirow[t]{2}{*}{$T:-101-5 Y-17 B-05$} & \multirow[t]{2}{*}{$\begin{array}{l}\text { TANK TEMP RISER } \\
\text { 17B, L.EVEL 76" }\end{array}$} & \multirow[t]{2}{*}{$\underset{{ }_{0} \mathrm{~F}}{12.5-32.5}$} & \multirow[t]{2}{*}{$s$} & B: 117.50 & $F: 71$ & $F: 105$ & $\begin{array}{c}\text { AL: }|3|, 10 \\
(130)\end{array}$ & $F: 139^{\circ}$ & $\xi$ \\
\hline & & & & & A:117.2 & D: 71.40 & ${ }^{D}: 105,30$ & $\underset{(135)}{\mathrm{AB}} 136.00$ & $\mathrm{D}: 138.60$ & $\Leftrightarrow$ \\
\hline
\end{tabular}

HNF-2351, Rev. 0 Page 27 of 35

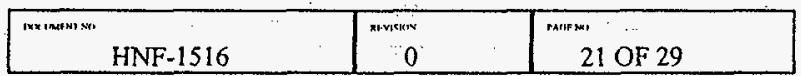




\section{THERMOCOUPLE MODULE HALT FAILURE ACCEPTANCE TEST PROCEDURE}

\begin{tabular}{|c|c|c|c|c|c|c|c|c|c|c|}
\hline $\begin{array}{l}\text { DACS } \\
\text { TAG }\end{array}$ & $\begin{array}{c}\text { FIELD TAG } \\
\text { NUMBER }\end{array}$ & DESCRIPTION & $\begin{array}{l}\text { SCALE/ } \\
\text { RANGE }\end{array}$ & $\begin{array}{l}\text { SELECTOR } \\
\text { SWITCH } \\
\text { POSIIION }\end{array}$ & $\begin{array}{c}\text { DACS } \\
\text { READING }\end{array}$ & $\begin{array}{l}\text { LOW END } \\
\text { READING }\end{array}$ & $\begin{array}{l}\text { MID } \\
\text { RANGE } \\
\text { READING }\end{array}$ & $\begin{array}{l}\text { ALARM/ } \\
\text { ABORT } \\
\text { VALUES } \\
\text { (DACS) }\end{array}$ & $\begin{array}{c}\text { HIGH } \\
\text { END } \\
\text { READING }\end{array}$ & INITIALS \\
\hline \multirow[t]{2}{*}{ TIRIJIBOG } & \multirow[t]{2}{*}{$T E-101-5 Y-1713-06$} & \multirow[t]{2}{*}{$\begin{array}{l}\text { TANK TEMP RISI:R } \\
\text { 17B, LEVILL 100" }\end{array}$} & \multirow[t]{2}{*}{$\begin{array}{c}12.5-325 \\
\text { F }\end{array}$} & \multirow{2}{*}{6} & B: 117.20 & 17: 71 & $F: 105$ & $\begin{array}{l}\wedge \mathrm{L}: 130.30 \\
(130)\end{array}$ & $F: 139$ & $g$ \\
\hline & & & & & $\wedge: 117,00$ & $D: 71,00$ & $D: 104.50$ & $\begin{array}{l}A B: 135,90 \\
(135)\end{array}$ & D: 140,00 & 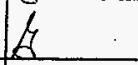 \\
\hline \multirow[t]{2}{*}{ TIRI71307 } & \multirow[t]{2}{*}{ TE- $101-S Y-1713-07$} & \multirow[t]{2}{*}{$\begin{array}{l}\text { TANK TEMP RISER } \\
\text { 17B, LEVEL } 112^{*}\end{array}$} & \multirow[t]{2}{*}{${ }_{{ }^{\prime} F}^{12.5-325}$} & \multirow[t]{2}{*}{7} & 3 & $r: 71$ & F: 105 & $\begin{array}{l}\text { AL: } 130,80 \\
(130)\end{array}$ & $F: 139$ & \\
\hline & & & & & & $D: 71.80$ & 105.30 & $\begin{array}{l}\mathrm{AB}: \\
(135) 134180\end{array}$ & D: 139.20 & 4 \\
\hline \multirow[t]{2}{*}{ TIR173308 } & \multirow[t]{2}{*}{$T E-101-5 Y-1713-08$} & \multirow[t]{2}{*}{$\begin{array}{l}\text { TANK TEMP RISER } \\
\text { I7B, LEVEL, 124" }\end{array}$} & \multirow[t]{2}{*}{$\underset{{ }^{\circ} \mathrm{F}}{12.5-325}$} & \multirow[t]{2}{*}{8} & & $F: 71$ & $\mathrm{~F}: 105$ & AL: 1301,00 & F: 139 & $\&$ \\
\hline & & & & & & $D: 71.70$ & 104.80 & $\begin{array}{l}A B: \\
(135)(35,40\end{array}$ & $\mathrm{D}: 140.00$ & 4 \\
\hline \multirow[t]{2}{*}{ TIRI7B09 } & \multirow[t]{2}{*}{ TE-101-SY-17B-09 } & \multirow[t]{2}{*}{$\begin{array}{l}\text { TANK TEMP RISER } \\
\text { 17B, LEVEL } 148^{n}\end{array}$} & \multirow[t]{2}{*}{$\underset{0}{12.5} \cdot 325$} & \multirow[t]{2}{*}{$?$} & & $F: 71$ & $\mathrm{~F}: 10 \mathrm{~s}$ & $\begin{array}{l}\mathrm{AL:} 130,00 \\
(130)\end{array}$ & $F: 139 \quad \ldots$ & 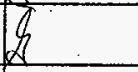 \\
\hline & & & & & 117,00 & D: 70.50 & D: 105.80 & $\begin{array}{l}A B: 134600 \\
(135)\end{array}$ & D: 139.50 & 2 \\
\hline \multirow[t]{2}{*}{ TIRI7BIO } & \multirow[t]{2}{*}{$71:-101-5 Y-17 B-10$} & \multirow[t]{2}{*}{$\begin{array}{l}\text { TANK TEMP RISER } \\
\text { 17B, LEVEL } 172^{*}\end{array}$} & \multirow[t]{2}{*}{ 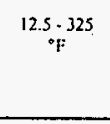 } & \multirow[t]{2}{*}{10} & 117,30 & $F: 71$ & $P: 105$ & $\begin{array}{l}1 \mathrm{~L} / 3099 \\
(130)\end{array}$ & $\mathrm{F}: 139$ & 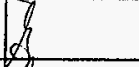 \\
\hline & & & & & $\therefore: 116.90$ & $0: 71,60$ & $0: 105,00$ & $\begin{array}{l}A B: 134.90 \\
(135)\end{array}$ & D: 139.80 & 4 \\
\hline \multirow[t]{2}{*}{ TIRI7BII } & \multirow[t]{2}{*}{ TE-101-SY-17B-11 } & \multirow{2}{*}{$\begin{array}{l}\text { TANK TEMP RISER } \\
\text { 178, LEVEL } 196^{n} \\
.\end{array}$} & \multirow[t]{2}{*}{$\underset{0}{12.5-325}$} & \multirow[t]{2}{*}{11} & ${ }^{B}: 117,70$ & F: 71 & $F: 105$ & $\begin{array}{l}A L(130.50 \\
(130)\end{array}$ & F: 139 & 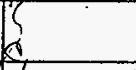 \\
\hline & & & & & $\therefore: 117,40$ & D: 70,90 & 104,90 & $\begin{array}{l}A B: 134,90 \\
(135)\end{array}$ & $D: 139,50$ & E \\
\hline \multirow[t]{2}{*}{ 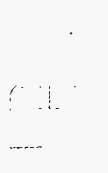 } & 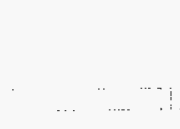 & .. & $\because \because$ & & & & . & 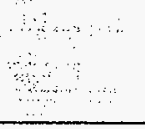 & & ' \\
\hline & HNF-235 & Rev. 0 Page 28 & $\overline{\mathrm{f}} \overline{\mathrm{s}}$ & & $|x \times 1 \ln x+m| \mathrm{st}$ & HNF-1516 & & $\begin{array}{l}0 \\
0\end{array}$ & 22 OF & 29 \\
\hline
\end{tabular}




\section{THERMOCOUPLE MODULE HALT FAILURE ACCEPTANCE TEST PROCEDURE}

\begin{tabular}{|c|c|c|c|c|c|c|c|c|c|c|}
\hline $\begin{array}{l}\text { DACS } \\
\text { TAG }\end{array}$ & $\begin{array}{l}\text { FIELD TAG } \\
\text { NUMBER }\end{array}$ & DESCRIPTION & $\begin{array}{l}\text { SCALE/ } \\
\text { RANGE }\end{array}$ & $\begin{array}{l}\text { SELECTOR } \\
\text { SWITCH } \\
\text { POSITION \# }\end{array}$ & $\begin{array}{c}\text { DACS } \\
\text { READING }\end{array}$ & $\begin{array}{l}\text { LOW END } \\
\text { READING }\end{array}$ & $\begin{array}{c}\text { MID } \\
\text { RANGE } \\
\text { READING }\end{array}$ & $\begin{array}{l}\text { ALARM/ } \\
\text { ABORT } \\
\text { VALUES } \\
\text { (DACS) }\end{array}$ & $\begin{array}{l}\text { HIGH } \\
\text { END } \\
\text { READING }\end{array}$ & INITIALS \\
\hline \multirow[t]{2}{*}{$T I R I 7 B 12$} & \multirow[t]{2}{*}{ TE-10I-SY-17B-12 } & \multirow[t]{2}{*}{$\begin{array}{l}\text { TANK TEMP RISER } \\
\text { 173, LEVELL 208* }\end{array}$} & \multirow{2}{*}{$\begin{array}{l}12.5-325 \\
n:\end{array}$} & \multirow[t]{2}{*}{12.} & 117.40 & I: 71 & $F: 105 \ldots$ & (is: 130$) 130.5$ & $F: 139$ & 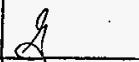 \\
\hline & & & & & & D. $71,40^{\circ}$ & D: 105,20 & $\begin{array}{l}A B: \\
(135) 135.5\end{array}$ & 139.60 & 4 \\
\hline \multirow[t]{2}{*}{ TiR17B13 } & \multirow[t]{2}{*}{$\mathrm{TE}-101-S Y-1713-13$} & \multirow[t]{2}{*}{$\begin{array}{l}\text { TANK TEMP RISER } \\
\text { 1713. LEVEL 220" }\end{array}$} & \multirow[t]{2}{*}{$\underset{*}{12.5-3.35}$} & \multirow[t]{2}{*}{13} & & $F: 71$ & $F=105$ & $\begin{array}{l}\text { A.: } \\
\text { (130) } 131,20\end{array}$ & $f: 139$ & $\&$ \\
\hline & & & & & & 071,80 & 105,90 & $\begin{array}{l}A B: \\
\text { (135) } 135.80\end{array}$ & ${ }^{D}: 139,80$ & 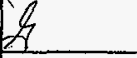 \\
\hline \multirow[t]{2}{*}{ TIRI7BI4 } & \multirow[t]{2}{*}{$T E-101-S Y-17 B-14$} & \multirow[t]{2}{*}{$\begin{array}{l}\text { TANK TEMP RISER } \\
\text { 17B, LEVEL 232* }\end{array}$} & \multirow[t]{2}{*}{${ }_{\cdot F}^{12.5-325}$} & \multirow[t]{2}{*}{14} & & $\mathrm{~F}: 71$ & $F: 105$ & (130) 139.9 & $F: 139$ & $\&$ \\
\hline & & & & & 117.50 & D: 71.80 & D: 105.70 & $\begin{array}{l}A B: \\
(135)(35.0\end{array}$ & D: 139,80 & $g$ \\
\hline \multirow[t]{2}{*}{ TIRI7B:5 } & \multirow[t]{2}{*}{ TE-101-SY-17B-1S } & \multirow[t]{2}{*}{$\begin{array}{l}\text { TANK TEMP RISER } \\
\text { 178, LEVEL 244" }\end{array}$} & \multirow[t]{2}{*}{$\begin{array}{c}12.5-325 \\
\circ \mathrm{F}\end{array}$} & \multirow[t]{2}{*}{ is } & & F: 71 & $F: 105$ & AL: 13077 & r: 139 & g \\
\hline & & & & & & $D^{D} 71,6$ & $\mathrm{D}: 105.30$ & AB: 134.70 & D: 139.10 & $\&$ \\
\hline \multirow[t]{2}{*}{ TIRI7B16 } & \multirow[t]{2}{*}{ TE-101-SY-17B-16 } & \multirow[t]{2}{*}{$\begin{array}{l}\text { TANK TEMP RISER } \\
\text { 178, LEVEL. } 268^{* 4}\end{array}$} & \multirow[t]{2}{*}{$\begin{array}{c}12.5-325 \\
{ }_{0} \mathrm{~F}\end{array}$} & \multirow[t]{2}{*}{16} & B: & $F: 71$ & $r: 105:$ & $\begin{array}{l}\lambda i 130.70 \\
(130)\end{array}$ & F: 139 & 4 \\
\hline & & & & & & D: 70,70 & 104.70 & $\begin{array}{l}\mathrm{AB}: 135.49 \\
(135)\end{array}$ & $D_{39.40}$ & $q$ \\
\hline \multirow[t]{2}{*}{ TIR17317 } & \multirow[t]{2}{*}{ TE-101-SY-17B-17 } & \multirow[t]{2}{*}{$\begin{array}{l}\text { TANK TEMP RISER } \\
\text { I7B, LEVEL 292" }\end{array}$} & \multirow[t]{2}{*}{$\begin{array}{c}12.5-325 \\
\circ \mathrm{F}\end{array}$} & \multirow[t]{2}{*}{17} & & $F: 7 t$ & $P: 105$ & $\begin{array}{l}A L: 130,20 \\
\text { (130) }\end{array}$ & F: 139 & \\
\hline & & & & & $\therefore: 117.10$ & D: 71,30 & D: 105,10 & $\begin{array}{l}A B: 134.80 \\
(135)\end{array}$ & $D: 139.50$ & $\sqrt{2}$ \\
\hline
\end{tabular}

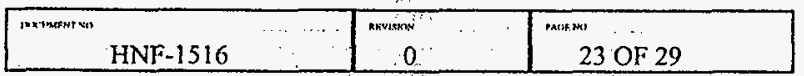




\section{THERMOCOUPLE MODULE HALT FAILURE ACCEPTANCE TEST PROCEDURE}

\begin{tabular}{|c|c|c|c|c|c|c|c|c|c|c|}
\hline $\begin{array}{l}\text { DACS } \\
\text { TAG }\end{array}$ & $\begin{array}{l}\text { FIELD TAG } \\
\text { NUMBER }\end{array}$ & DESCRIPTION & $\begin{array}{l}\text { SCALE/ } \\
\text { RANGE }\end{array}$ & $\begin{array}{l}\text { SELECTOR } \\
\text { SWITCH } \\
\text { POSITION \# }\end{array}$ & $\begin{array}{c}\text { DACS } \\
\text { READING }\end{array}$ & $\begin{array}{l}\text { LOW END } \\
\text { READING }\end{array}$ & $\begin{array}{c}\text { MID } \\
\text { RANGE } \\
\text { READING }\end{array}$ & $\begin{array}{l}\text { ALARM/ } \\
\text { ABORT } \\
\text { VALUES } \\
\text { (DACS) }\end{array}$ & $\begin{array}{c}\text { HIGH } \\
\text { END } \\
\text { READING }\end{array}$ & INITIALS \\
\hline \multirow[t]{2}{*}{ TIRI71318 } & \multirow[t]{2}{*}{ TE-101-SY-17B-18 } & \multirow[t]{2}{*}{$\begin{array}{l}\text { TANK TEMP RISER } \\
\text { I7B, LEVEL 326" }\end{array}$} & \multirow[t]{2}{*}{$\underset{\substack{12.5 \\
{ }_{0}}}{1.325}$} & \multirow[t]{2}{*}{18} & 117.10 & $F: 71^{2}$ & F: 105 & (150) 130,20 & $F: 139$. & \\
\hline & & & & & 116,90 & D: 7120 & D: $10480^{\circ}$ & $\begin{array}{l}A B: 132.30 \\
(135)\end{array}$ & $D: 139.2$ & 21 \\
\hline \multirow[t]{2}{*}{ TIRI7BI9 } & \multirow[t]{2}{*}{ TEE-101-SY-17B-19 } & \multirow[t]{2}{*}{$\begin{array}{l}\text { TANK TEMP RISER } \\
\text { 1713. LUVEL } 340^{*}\end{array}$} & \multirow[t]{2}{*}{$\underset{n i}{12.5-325}$} & \multirow[t]{2}{*}{19} & 116,70 & $F: 71$ & $P: 105$ & 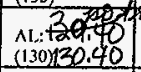 & F: 139 & 8 \\
\hline & & & & & & D: 71.20 & ${ }^{0} 105110$ & $\begin{array}{l}A B: 135,30 \\
(135)\end{array}$ & $\begin{array}{l}138.40 \\
135.38\end{array}$ & \\
\hline \multirow[t]{2}{*}{ TIRI7B20 } & \multirow[t]{2}{*}{ TE-101-SY-17B-20 } & \multirow[t]{2}{*}{$\begin{array}{l}\text { TANK TEMP RISER } \\
\text { I7B, LEVEL } 364^{\circ}\end{array}$} & \multirow[t]{2}{*}{${ }_{\circ}^{12.5} \cdot-325$} & \multirow[t]{2}{*}{20} & 110,70 & $\begin{array}{c}\mathrm{F}: 71 \\
\mathrm{~b}\end{array}$ & $F: 105$ & $\begin{array}{l}\text { AL: } 130.20 \\
(130)\end{array}$ & ri: 139 & 8 \\
\hline & & & & & $A: 110.30$ & $\mathrm{D}: 71,30$ & 05.50 & $\begin{array}{l}A B: 135.5 \\
(135)\end{array}$ & D: 139,40 & \\
\hline \multirow[t]{2}{*}{ TIRI 71321} & \multirow[t]{2}{*}{$T E=-101-S Y-1713-21$} & \multirow[t]{2}{*}{$\begin{array}{l}\text { TANK TEMP RISER } \\
\text { 17B, LEVEL } 392^{"}\end{array}$} & \multirow[t]{2}{*}{$\underset{\circ}{12.5-3.35}$} & \multirow[t]{2}{*}{21} & $8: 88.90$ & $F: 7 !$ & Fiố & $\mathrm{AL}=130.2 \mathrm{O}$ & $\mathrm{p}: 139$ & \\
\hline & & & & & $\wedge 88.50$ & $\mathrm{D}: 71.80$ & 105.30 & $\begin{array}{l}13: 130,20 \\
(135) 135,30\end{array}$ & D: 139.30 & $\lambda$ \\
\hline \multirow[t]{2}{*}{ TIRI7B22 } & \multirow[t]{2}{*}{ TE $101-\$ Y-17 \mathrm{~B}-22$} & \multirow[t]{2}{*}{$\begin{array}{l}\text { TANK TEMP RISER } \\
\text { I7B. LEVEL } 402^{*}\end{array}$} & \multirow[t]{2}{*}{$\begin{array}{c}12.5-325 \\
{ }^{\circ} \mathrm{F}\end{array}$} & \multirow[t]{2}{*}{22} & $8: 81,30$ & F: 71 & pios & $\begin{array}{l}A 130.79 \\
(130)\end{array}$ & $F: 1399,00$ & 4 \\
\hline & & & & & 81.10 & $\mathrm{D}: 71.40$ & 105.80 & $\begin{array}{l}A B: 134: 79 \\
(135)\end{array}$ & $D_{i} 39,00$ & 1 \\
\hline
\end{tabular}

HNF-2351, Rev. 0 Page 30 of 35

\begin{tabular}{|c|c|c|}
\hline HNF-1516 & $\begin{array}{r}{ }_{\text {RFustris }} \\
0\end{array}$ & 24 OF 29 \\
\hline
\end{tabular}




\section{THERMOCOUPLE MODULE HALT FAILURE ACCEPTANCE TEST PROCEDURE}

\begin{tabular}{|c|c|c|c|c|c|c|c|c|c|c|}
\hline $\begin{array}{l}\text { DACS } \\
\text { TAG }\end{array}$ & $\begin{array}{l}\text { FIELD TAG } \\
\text { NUMBER }\end{array}$ & DESCRIPTION & $\begin{array}{l}\text { SCALE/ } \\
\text { RANGE }\end{array}$ & $\begin{array}{c}\text { SIGNAL } \\
\text { INPUT } \\
\text { CONNECTN } \\
\text { POINTS }\end{array}$ & $\begin{array}{c}\text { DACS } \\
\text { READING }\end{array}$ & $\begin{array}{l}\text { LOWEND } \\
\text { READING }\end{array}$ & $\begin{array}{c}\text { MID } \\
\text { RANGE } \\
\text { READING }\end{array}$ & $\begin{array}{l}\text { ALARMI } \\
\text { ABORT } \\
\text { YALUES } \\
\text { (DACS) }\end{array}$ & $\begin{array}{l}\text { HIGH } \\
\text { END } \\
\text { READING }\end{array}$ & INITIALS \\
\hline \multirow[t]{2}{*}{ TIR:7C07 } & \multirow[t]{2}{*}{ TE:-101-SY-17C-07 } & \multirow{2}{*}{$\begin{array}{l}\text { TANK TEMP RISI:R } \\
\text { 17C, LEVEL } \| 12^{*}\end{array}$} & \multirow[t]{2}{*}{$70-140^{\circ} \mathrm{F}$} & \multirow{2}{*}{$\begin{array}{c}\text { GMSI } \\
\text { TB } 4 \\
\text { TERMS } 7,8 \\
\end{array}$} & $B: 117.30$ & $F: 71$ & F: 105 & AL: N/A. & $\mathrm{F}: 139$ & \multirow{2}{*}{$\notin$} \\
\hline & & & & & $A: 117.00$ & $\mathrm{D}: 70.60$ & D: $104: 20$ & $A B: N / A$ & $D: 138,80$ & \\
\hline \multirow[t]{2}{*}{ TIRITC18 } & \multirow[t]{2}{*}{$T E-101-S Y-17 C-18$} & \multirow{2}{*}{$\begin{array}{c}\text { TANK TEMP RISEER } \\
\text { I7C, LEVEL } 340^{*}\end{array}$} & \multirow[t]{2}{*}{$70-140^{n F}$} & \multirow{2}{*}{$\begin{array}{c}\text { GMSI } \\
\text { TB } 6 \\
\text { TIERMS } 16,17\end{array}$} & $B: 116,30$ & F: 71 & $F: 105$ & $A L: N / A$ & $F: 139$ & \multirow{2}{*}{4} \\
\hline & & & & & A: 115.80 & $1: 71_{1} 60$ & $D: 104,90$ & $A B: N / A$ & D: 138.80 & \\
\hline \multirow[t]{2}{*}{ T[R] $7 C 20$} & \multirow[t]{2}{*}{$T E-101-5 \gamma-17 C-20$} & \multirow{2}{*}{$\begin{array}{l}\text { TANK TEMP RISER } \\
\text { 17C, LEVEL } 392^{n}\end{array}$} & \multirow[t]{2}{*}{$70-140^{\circ} \mathrm{F}=$} & \multirow{2}{*}{$\begin{array}{c}\text { GMSI } \\
\text { TB S } \\
\text { TERMS } 19,20 \\
\end{array}$} & B: 87,60 & F: 71 & $\mathrm{~F}: 105$ & AL:N/A & $\mathrm{F}: 139$ & \multirow{2}{*}{ zobylar $\&$} \\
\hline & & & & & $1: 87.10$ & $D: 71,30$ & $D: 105.30$ & $A B: N / A$ & & \\
\hline \multirow{2}{*}{ Tastcio } & \multirow{2}{*}{$\begin{array}{l}\text { TE-101 } \\
\operatorname{Pr} 10\end{array}$} & \multirow{2}{*}{$\begin{array}{l}\text { TANK BOTTOM } \\
\text { THERMOCOUPLE }\end{array}$} & \multirow[t]{2}{*}{$50-200^{\circ} \mathrm{F}$} & \multirow{2}{*}{$\begin{array}{l}T B X X-101 \\
+10 \&-10\end{array}$} & B: 80,0 & Av:5sa 87.55 & F: $: 25$ & AL: N/A & F: 195 & \multirow{2}{*}{4} \\
\hline & & & & & 1. 80.0 & 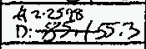 & D: $1 \frac{125,3}{3,4}$ & $A B: N / A$ & D: 193,6 & \\
\hline \multirow[t]{2}{*}{ THSTC17 } & \multirow{2}{*}{$\begin{array}{l}\text { TEE } 101 \\
\operatorname{Pr} 17\end{array}$} & \multirow{2}{*}{$\begin{array}{l}\text { TANK BOTTOM } \\
\text { THERMOCOUPLE }\end{array}$} & \multirow[t]{2}{*}{$50.200{ }^{\circ} \mathrm{F}$} & \multirow{2}{*}{$\begin{array}{c}713 \times-101 \\
+17 \&-17\end{array}$} & B: 96.2 & $F: 55-$ & $\mathrm{F}: 125$ & AL:N/A & $F: 195$ & \multirow{2}{*}{4} \\
\hline & & & & & A. 96.3 & D: 55.9 & $D: 124,4$ & $A B: N / A$ & D: 194,8 & \\
\hline \multirow[t]{2}{*}{ THSTC24 } & \multirow{2}{*}{$\begin{array}{l}\mathrm{Tt} \cdot 10 \mathrm{t} \\
\mathrm{Pr} 24\end{array}$} & \multirow{2}{*}{$\begin{array}{l}\text { TANK BOTTOM } \\
\text { THERMOCOUPLE }\end{array}$} & \multirow[t]{2}{*}{$50-200^{\circ} \mathrm{F}$} & \multirow{2}{*}{$\begin{array}{r}7 B X-101 \\
+24 \&-24\end{array}$} & B:140.0 & F: 55. & $F: 125$ & $A L: N / A$ & $F: 195$ & \multirow{2}{*}{2} \\
\hline & & & & & $\mathrm{A}: 140.0$. & D: $\begin{array}{l}55.7 \\
5.44\end{array}$ & $D: 124,8$ & $A B: N / A:$ & $D: 195.5$ & \\
\hline
\end{tabular}

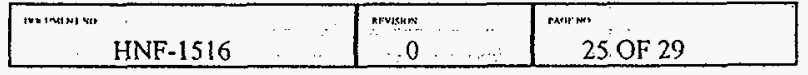




\subsection{ATTACHMENTS}

Attachment 1, Exception List

Attachment 2, Measurement and Test Equipment Record Sheet

Attachment 3, Final Procedure Acceptanice Sheet 


\section{THERMOCOUPLE MODULE HALT FAILURE ACCEPTANCE TEST PROCEDURE}

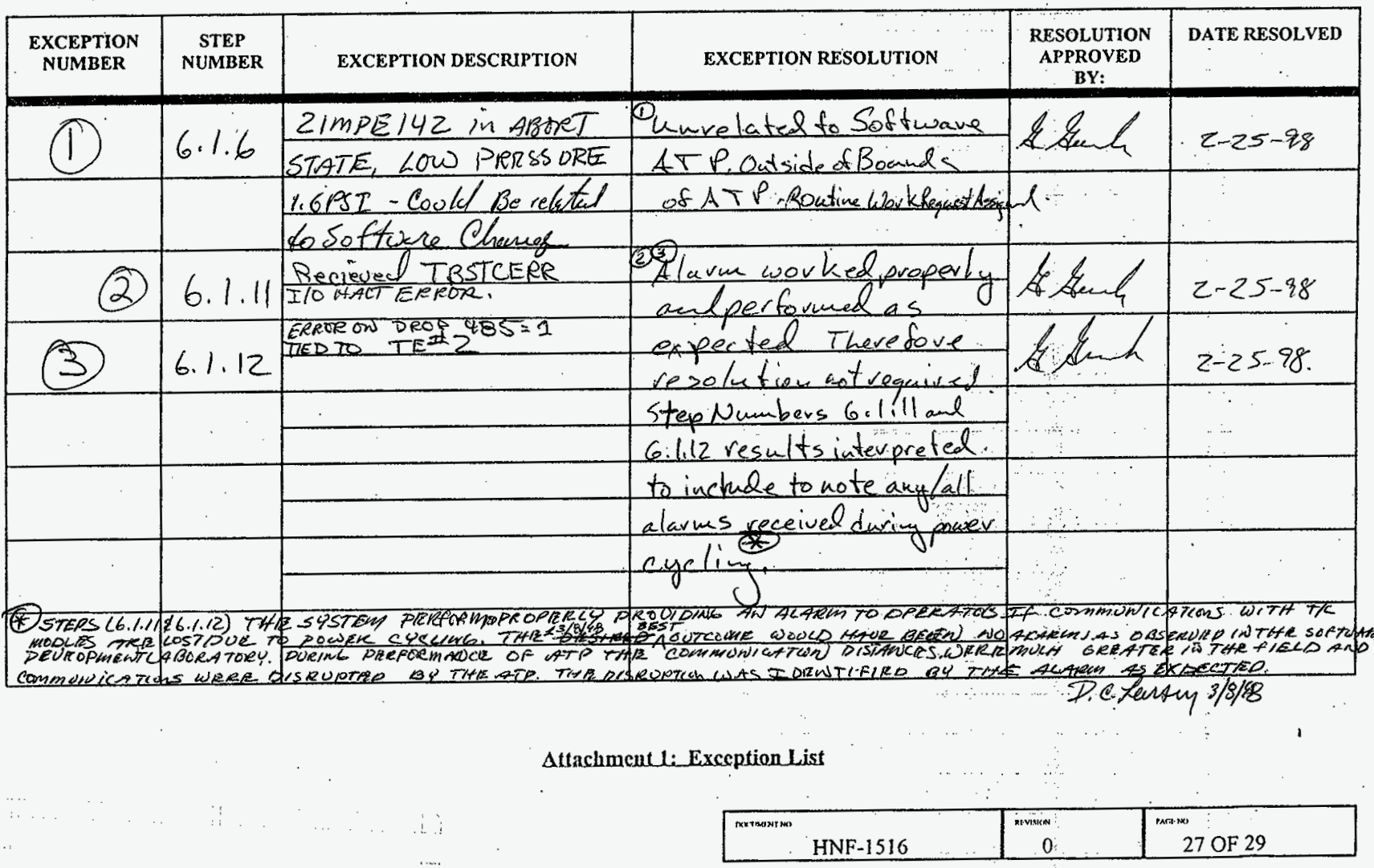


THERMOCOUPLE MODULE HALT FAILURE ACCEPTANCE TEST PROCEDURE

\begin{tabular}{|c|c|c|c|c|c|}
\hline MANUFACTURER & MODEL & SERIAL NO. & $\begin{array}{l}\text { CALIBRATION } \\
\text { DUE DATE }\end{array}$ & $\begin{array}{c}\text { CALIBRATION } \\
\text { TRACKING } \\
\text { CODE }\end{array}$ & USE DESCRIPTION \\
\hline Transmation & 1080 & 07569107 & $9 / 15 / 48$ & $812 \cdot 13-20 \cdot 024$ & TC input for MIT \\
\hline Transmation. & $1064 p$ & 6983608 & $11 / 6 / 98$ & $817-13-20-020$ & Te input for Tenk bottom Side \\
\hline & & & & $\ldots$ & \\
\hline & & & & $\because$ & \\
\hline & & & & & \\
\hline & & & & & \\
\hline & & & & & \\
\hline & & & & & \\
\hline & & & & & \\
\hline & & & & & \\
\hline & & & & $\therefore$ & \\
\hline & & & & & \\
\hline & & - & & & \\
\hline & & & & & \\
\hline \multicolumn{6}{|c|}{ Attaclement 2:-Measurement and Test Equipment Record Sheet } \\
\hline & & & 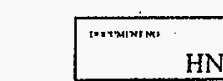 & \begin{tabular}{|r|r}
1516 & \\
\end{tabular} & 28 OF 29 \\
\hline
\end{tabular}


Completion of this procedure has demonstrated that:

- The Data Acquisition and Control System (DACS) provides satisfactory monitoring and alarming of the thermocouple module halt fallure:

The modified DACS screens provide a satisfactory operator interfacc.

A record of all noted deficiencies was kept on Attachment 1, Exception List, and all recorded exceptions have been resolved and the resolutions approved.

Approved by:

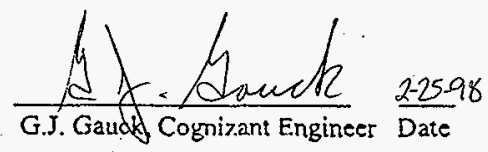

Jeff A. Ranschan

Ifff Ranuchmon for C. S. Hrogrind 2-25-98

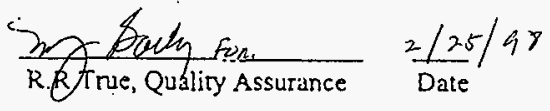

Attactment 3: Final Procedure Acceptance Sheet

\begin{tabular}{|c|c|c|}
\hline HNF-1516 & ${ }_{0}^{m}$ & $\cdots n$ \\
\hline
\end{tabular}




\section{DISTRIBUTION SHEET}

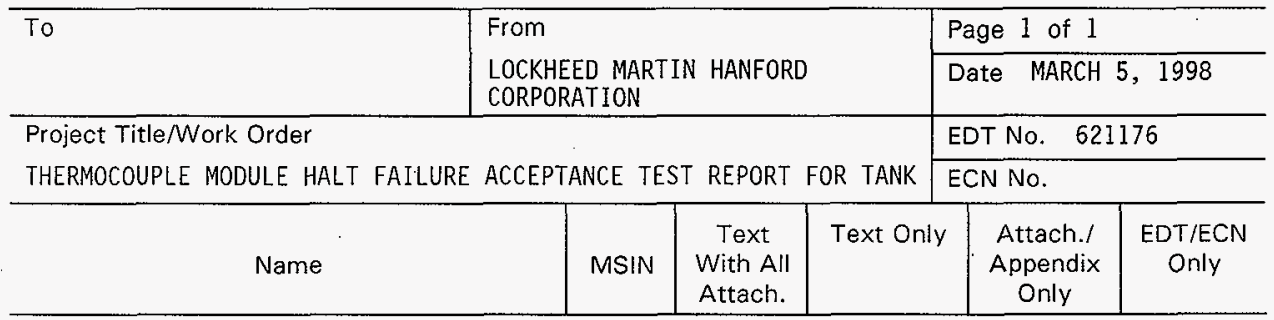

W. G. Brown

D. W. Crass

J. A. Ellingsworth

A. M. Ermi

G. J. Gauck

L. S. Krogsrud

D. C. Larsen

R. E. Larsen

D. D. Tate

R. W. Truitt

R. R. True

R. P. Tucker

S. 0. Smith / A. C. Zuehlke

DACS Project File

Central files
T4-07

H6-11

R2-87

L6-37

T4-08

T4-07

T4-08

T4-07

16-37

L6-37

T4-07

T4-08

L6-37

L6-37

B1 -07 $x$

$x$
$x$

$x$ 